\title{
Introduction Latent Variables for Estimating Airline Assessment
}

\author{
Hashem Salarzadeh Jenatabadi ${ }^{1}$ \\ ${ }^{1}$ Applied Statistics Department, University of Malaya, Kuala Lumpur, Malaysia \\ Correspondence: Hashem Salarzadeh Jenatabadi, Applied Statistics Department, University of Malaya, Kuala \\ Lumpur, Malaysia. Tel: 60-17-877-7662. E-mail: hashem.salarzadeh@gmail.com
}

Received: June 30, 2013

Accepted: July 29, 2013

Online Published: August 20, 2013

doi:10.5539/ijbm.v8n18p78

URL: http://dx.doi.org/10.5539/ijbm.v8n18p78

\begin{abstract}
This paper focuses on the application of latent variables in assessing airline performance. There is a gap in literature of airline performance modelling. This paper, based on latent variable model attempts to introduce a new framework for airline assessment modelling. In this regard, organisational assessment was used as theoretical framework. Four constructs and thirteen measurements are illustrated for airline assessment model.
\end{abstract}

Keywords: organisational assessment, airline assessment, latent variables

\section{Introduction}

After the determination and definition of research variables, previous research models consider each of the performance indicators (dependent variables) separately and present different models with different dependent variables for each indicator in assessing airline performance. This gap in these studies shows that the models used were not able to introduce the "overall general performance indicator". General indicator is a combination of various indicators including load factor, market share and number of passengers, among others. The models used in past studies fail to introduce a single unified model to address this objective. For instance, the study of Rajasekar and Fouts (2009) used three indicators -RPM, passenger load factor, and market share to estimate performance and presented a separate model for each indicator. However, these measurable indicators are in the same area of airline performance. It is clear that they are related, hence, a change in anyone causes changes in others. As a result, it is appropriate to combine these indicators as one construct and call it "overall performance".

In this paper we are trying to fill the gap with introduction of latent variable instead of measurement variable. Moreover, in airline industry studies, there is less effective methodology in assessing airline performance. The second objective of this article is to determine airline performance assessment tools. This approach is often overlooked in assessing airline performance based on airline capacity and capability. Also this paper does not focus only on testing and estimating but discusses modelling systems to assess airline companies' performance. We will be discussed some key applicable constructs in the later sections.

\section{Literature Review}

Latent variable models have used in many fields of study including food industry (Aghdaie, Dolatabadi, \& Adibparsa, 2012; Hosseini, Azizi, \& Sheikhi, 2012), hotel industry (Abukhalifeh \& Som, 2012) educational sector (Chung \& Tan, 2008; Zhang, Han, \& Gao, 2008), and air transport (Chen \& Kao, 2011; Chiou \& Chen, 2010; Martín-Consuegra \& Esteban, 2007) studies. Although latent variables are statistical data concepts, there is no single definition that would incorporate all the diverse applications. However, there are latent variables definitions that are closely linked to specific statistical concepts. The systematic comparisons of these different definitions and the implications of these differences are made. Furthermore, latent variables are associated with diverse definitions that are linked to limited applications.

Lawler, Nadler, and Cammann (1980) define assessment as a procedure of evaluating the effectiveness of the company based on social and behavioural perception. Ford and Evans (2001) believe that the models are an essential factor in organizational assessment and the model answers a substantial question of "what gets assessed?". Nevertheless, organisational assessment utilize the model whether the model's assumption is comprehensive or not (Hausser, 1980). An assessment model contains some constructs to determine organisational behavior. In the assessment model at least one construct presents an outcome measure (Ford \& Evans, 2001). It can assess various aspects of the organisation like group behavior (Ancona, 1990), health care 
(Keller, Borges, Hoke, \& Radasa, 2011), non-profit organization (Gope \& Hsu, 2011), enterprise transformation (Valerdi \& Abdimomunova, 2010), program change (Courtney, Joe, Rowan-Szal, \& Simpson, 2007), and quality performance (Rhydderch et al., 2005).

Lusthaus (2002) introduced and developed organisational assessment framework which included four constructs. These are external operating environments, internal environment and organisational capacity which are the three main factors affecting on organisational performance.

Organisational capacity includes programme and process management, IT and technology, strategic leadership, financial resources, physical infrastructure, staffing, and its links with other business groups and companies. Management capacity covers managing processes and procedures of its programmes and resources as well as the external relationships of the organisation with other firms and companies. These management capacities and resources together constitute the organisation's overall capacity. External operating environment includes political environment, economic conditions and trends, legal and administrative systems, and the cultural and social contexts under which the company operates. These have significant effect on the capability, capacity and performance of the company. For example, the legal systems introduce and govern the policies, rules and regulations of the company. The political environment includes factors that have a vital impact on the existence and survival of the organisation. These factors can be general political stability or political support or hostility in a country by other political powers. The internal environment "refers to internal indicators that influence the direction of the organisation and the energy displayed in its activities" (Metzger, 2007).

\section{Method}

\subsection{Research Framework}

The conceptual framework used in this research is the same theory discussed above, which has been justified and applied to the airline industry. Therefore, according to the introduced theory, the final model suggested by this paper includes four main constructs, namely: performance, airline capability, economic situation and airline capacity, as illustrated in Figure 1.

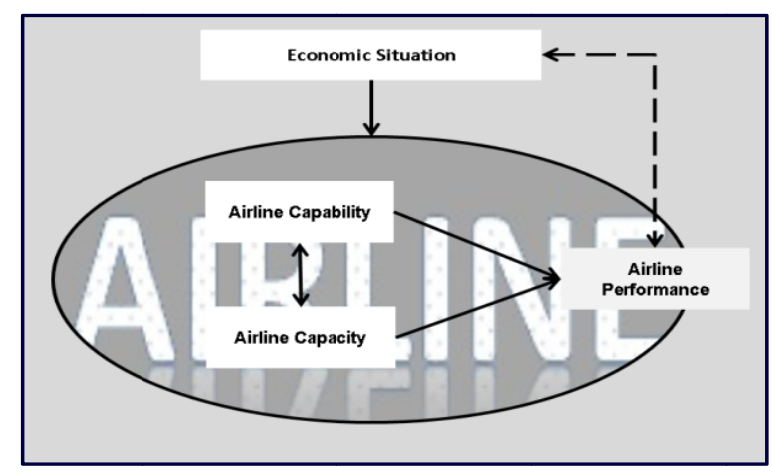

Figure 1. Airline assessment framework

\subsubsection{Airline Capacity Construct}

Lusthaus (2002) stated that organisational capacity includes management (networking and linkage, programme and process management, and leadership) and resources (physical, human, technological, and financial). Due to the data structure, number of employees of the company is a characteristic of determining human resources, available seat kilometre (ASK) for physical and financial resources, and network size indicator refers to networking, financial, and technological resources. Hence, the airline capacity indicators presented in this study are network size, number of employees, and ASK.

\subsubsection{ASK}

According to Beaver (2005), ASK is the result of the number of passengers on an aircraft multiplied by the route distance. In other words, one unit of ASK is one seat over a kilometre on the route. It is apparent that the definition of ASK is the combination of distance between routes and number of available seats on a flight of the same route. The number of seats and distance variables reflect the number of airplanes and the distances they transport passengers. Hence, in this study, ASK is be considered as a measurement of airline capacity. 


\subsubsection{Network Size}

The size of a network can be calculated by the number of station pairs between which the airline can transport passengers (Brueckner, Dyer, \& Spiller, 1992). The network size plays an important role in transporting passengers around various stations as there is a direct relationship between the airline industry network size and the number of passengers. This has an ultimate effect on the load factor and operating profit, among others. Therefore, an increasing network size enhances the airline industry's overall performance. However, network size variable is rarely used in airline industry analysis.

\subsubsection{Number of Employee}

Number of employees refers to the number of part time or full time employees hired yearly by an industry.

\subsubsection{Airline Capability Construct}

Airline capability or airline operational capability is a vital construct in airline companies which contains indicators under the control of management that are changed based on companies' policies or strategies. We define this construct with four dimensions including; average stage of length, number of flights, aircraft kilometre, and advertising \& promotions expenses based on the studies of Duliba, Kauffman, and Lucas Jr (2001).

\subsubsection{Number of Flights}

The number of flights refers to the availability and accessibility of an airline to its customers. Provision of more flights would normally enhance better passenger satisfaction and convenience. This promotes airline reputation and attracts more passengers in the market. In the section of data analysis, departures represent number of flights.

\subsubsection{Average Stage of Length}

Doganis (1991) defines Average Stage of Length (ASL) as the length flown divided by the number of the departures. This factor shows the average length in miles or kilometres of a flight between the departure point and destination, which can be two cities or routes in the case of transit flights. The ASL measurement enables airlines to better perform financially. Financial performance is enhanced with a longer ASL. Furthermore, the value of a longer ASL is associated with the number of landings and take-offs in a time period which can be reduced ultimately.

\subsubsection{Aircraft Kilometer}

Airline kilometer is very commonly used measure of air travel, computed by multiply each weighted airplane trip by the distance. One aircraft kilometer is a kilometer travelled by an aircraft irrespective of the number of passengers on the aircraft.

\subsubsection{Advertisement \& Promotion Expenses}

In the data analysis, advertisement represents advertising and promotion expenses measured in US dollars. However, it is important to note that some annual reports used different monetary units other than the US dollar to value advertisement expenses. In this research, all other currencies are converted into US dollars for uniformity and ease of comparison.

\subsubsection{Airline Performance Construct}

Airline Performance is a combination of operational, financial and marketing performance. Based on the research of Duliba et al. (2001), four performance indicatorsare taken into consideration in measuring airline performance construct. These are operating profit (financial performance), load factor (operational or financial performance), market share (marketing performance) and revenue passenger kilometre (operational performance).

\subsubsection{Load Factor}

Load factor is the most essential function of operational performance in the airline industry. It is the main important objective of all airline managers to improve the value of this factor. Therefore, this research has also taken the load factor as one of the most important factors to evaluate the performance of airline company. The mathematical definition of load factor would be as follows:

$$
\text { Load Factor }=\frac{\sum(\text { Number of Passengers Carried } * \text { Distance })}{\sum(\text { Number of Avalable Seats } * \text { Distance })}
$$


In the above equation,

- Number of Passengers Carried represents the number of the transported passengers on a route between two stations, departure point and destination.

- Station refers to two flight points, either two cities within the borders of a country, or two cities in two different countries.

- Distance stands for the variable of distance between departure station and destination, which is gauged in kilometres in this study.

- Available Seats represents the number of available seats on board an aircraft and changes from one aircraft to another according to the type.

\subsubsection{Operating Profit}

Operating profit refers to growth in business activities in favour of the business owners in a market. "Profit" is originally a Latin word which means "to make progress". In this study, operating profit was based on the annual reports of airline companies in US dollars.

\subsubsection{Revenue Passenger Kilometre}

According to Petrick (2007), "RPK is a measure for passenger traffic, obtained by multiplying the number of paying passengers on a flight by the distance of the flight". RPK is similar to operating profit by contributing to growth of the company in the market. RPK is calculated using the number of passengers and the covered distance; therefore, it can be applied to the analysis of organisational performance.

\subsubsection{Market Share}

Market share refers to a percentage or proportion of the available market or its division that is covered by the service a company offers. Market share is also known as the sales income of a company earned from the same market divided by the total profits coming from sales within that market. It may also be known as the unit sales volume of a company in a market divided by the total amount of units sold in the same market. Concerning the common definition of Market Share in the airline industry, Ceha and Ohta (2000) have introduced a definition as follows:

$$
{\text { Market } \text { Share }_{i}}_{=} \frac{P A X_{i}}{\sum_{i=1}^{n} P A X_{i}}
$$

In the above equation, $P A X_{i}$ shows the number of passengers carried by $\mathrm{i}^{\text {th }}$ airline and $n$ refers to the number of airlines activated in the market.

Finding the value of market share helps airline companies to be able to evaluate their situation in the competitive market in the airline industry to find an effective and efficient marketing strategy.

\subsubsection{Economic Situation Construct}

GDP is one of the most essential economic variables employed in different economic modeling in airline studies (Detzen, Jain, Likitapiwat, \& Rubin, 2012; Gillen, 2010; Guzhva \& Pagiavlas, 2004; Ramanathan, 2001). GDP is considered as an effective factor which significantly influences airlines performances. Another economic factor is inflation rate indicator that significantly affects the countries`economies and performance of the organisations contributing to the evaluation and assessment of consumers' purchasing power. This factor has also been used for evaluation of the airline industry performance by different researchers such as Aderamo (2010) and Salarzadeh Jenatabadi and Ismail (2007). The Human Development Index (HDI) is also another indicator which has played a significant role among other factors in recent years although it has never been applied to significant studies related to the airline industry. This study, therefore, intends to employ HDI along with GDP and Inflation Rate to measure the economic environments.

\subsubsection{GDP}

According to Bernold and AbouRizk (2010), GDP "is equal to the total expenditures for all final goods and services produced within a country during a given year". The following equation displays the components of equation that results in GDP:

$$
G D P=\text { government spending + gross investment }+ \text { private consumption }+(\text { exports-imports) }
$$




\subsubsection{Inflation Rate}

Generally, the most important and direct impact of inflation rate is on people's lives as well as the performance of the organisation (Wimmers, Optiz, \& Mayer, 2009). According to the research of Smith and Searle (2010), "the inflation rate is the year-on-year growth rate of the consumer price index". The inflation rate can be mathematically defined as follows:

If Price $_{t}$ represents the average price during year $\mathrm{t}$ and Price $_{t-1}$ is the average price in year $\mathrm{t}-1$, the resulting inflation rate for year ${ }_{t}$ will be obtained through:

$$
\text { Inflation } \text { Rate }_{t}=\frac{\text { Price }_{t}-\text { Price }_{t-1}}{\text { Price }_{t-1}} \times 100 \%
$$

Therefore, inflation rate should be utilised as one of the research variables that may have an impact on the performance of the airline; however, this factor is not applicable to the management of airlines. This economic factor, i.e., inflation rate, enables prediction of the ticket price in the airline industry in the US (Bachis \& Piga, 2006). Hence, this study considered inflation rate as a measurement in the construct of the economic condition.

\subsubsection{HDI}

According to Avakov (2010), the HDI is the "average of the level of income per capita in purchasing power parties, level of education, and the level of health care". This value ranges between 0 and 1 . The countries that depend on their HDI are classified into three categories, namely: the countries with their HDI below 0.500 (countries with low rate of HDI), those with their HDI ranging from 0.500 to 0.800 (countries with medium HDI), and countries with over 0.800 HDI (countries with high HDI) (Gachino, 2006).

\subsection{Sample}

Airline organisations are classified as a service-providing sector, thus provision of services to their customers or passengers. These sorts of companies are grouped into three categories based on the kind of service:

a) Cargo transfer,

b) Passengers transfer,

c) Passenger and cargo transfer.

However, this study focuses on the airline companies specialising on passenger transfer although they also concurrently provide services for cargo transfer. Moreover, the cargo transferring aspects have been excluded from this research domain.

In this study, based on Air Transport World (ATW) database, 214 airlines were chosen using stratified sampling during which five companies were terminated from the sample due to outlier and missing data. Therefore, the final number of sample is 209 airlines.

\subsection{Measurement Model Analysis}

Three procedures have been proposed by Fornell and Larcker (1981) to evaluate the convergent validity of the measurement model, namely, reliability of measures, each construct's composite reliability and the Average Variance Extracted (AVE). An item's reliability was assessed through the factor loading of the item onto the underlying construct. According to Hair, Black, Babin, Anderson, and Tatham (2006), a factor loading of 0.7 indicates that the validity of an item is acceptable. We have utilised the composite reliability in this study instead of Cronbach's alpha since the latter one, as Hair et al. (2006) argues, has a strong tendency to understate the level of reliability. Nunally and Bernstein (1994) recommended a value of 0.7 or higher for the composite reliability to be considered as adequate. For the third index of convergent validity, AVE, Fornell and Larcker (1981) suggested that it "measures the overall amount of variance that is attributed to the construct in relation to the amount of variance attributable to measurement error". According to Segars (1997), convergent validity is considered as adequate if the AVE is 0.50 or higher. As illustrated in Table 1, all factor loadings were higher than the minimum and could meet the guidelines recommended by relevant researchers with the exception of inflation rate. However, inflation rate can be included in the data analysis due to its significant correlation (Teo, 2010) i.e., $(r=-0.601)$, with other items, in (GDP), in the same construct. 
Table 1. Results of measurement model

\begin{tabular}{|c|c|c|c|c|}
\hline Constructs & Indicators & Factor Loading $(>0.70)^{*}$ & Cronbach's Alpha $(>0.70)^{*}$ & $\operatorname{AVE}(>0.50)^{*}$ \\
\hline \multicolumn{3}{|c|}{ Airline Capacity } & 0.71 & 0.57 \\
\hline & ASK & 0.77 & & \\
\hline & Network Size & 0.73 & & \\
\hline & Number of Employee & 0.76 & & \\
\hline \multicolumn{3}{|c|}{ Airline Performance } & 0.81 & 0.65 \\
\hline & Load Factor & 0.78 & & \\
\hline & Market Share & 0.88 & & \\
\hline & RPK & 0.84 & & \\
\hline & Operating Profit & 0.71 & & \\
\hline \multicolumn{3}{|c|}{ Airline Capability } & 0.88 & 0.85 \\
\hline & Departure & 0.90 & & \\
\hline & Stage of Length & 0.93 & & \\
\hline & Advertisement & 0.93 & & \\
\hline & Aircraft Kilometre & 0.93 & & \\
\hline \multicolumn{3}{|c|}{ Economic Situation } & 0.78 & 0.57 \\
\hline & Inflation Rate & 0.62 & & \\
\hline & $\operatorname{Ln}(\mathrm{GDP})$ & 0.97 & & \\
\hline & HDI & 0.87 & & \\
\hline
\end{tabular}

\section{Discussion}

Several studies in airline industry have focused on performance assessment using internal indicators as independent variables while many other works used external indicators to assess factors that impact on performance. In these studies, all the research indicators have been used as one or multiple measurements. Several studies have introduced different factors in assessing performance using distinct models. For example, revenue passenger kilometre and load factor considered as performance indicators were examined in two different ways with each independent variable having different coefficients.

There are two different coefficients of examining factors affecting performance indicators such as inflation rate or GDP. However, these measurements fall short of assessing the entire performance. Further, these models fail to address how the economic indicators (inflation rate, HDI and GDP) impact on airline companies' performance.

The study contributes to literature by using constructs or latent variables contrary to observed variables in airline capability, capacity, economic and performance in earlier studies. Latent variables are preferred to measure variables due to the fact that each construct or latent variable has many observed indicators. Therefore, four construct variables are introduced in airline assessment model of which the first is economic variable replacing inflation rate and GDP which were separately used in previous studies. The research's second contribution is the use of HDI as an important economic variable where all the three measurements are considered one construct in the economy. The second construct is referred to as airline capability and the third as airline performance which are measured by earlier works of Duliba et al (2001).

The third contribution of the study is the use of airline capacity construct to assess important factors impacting on the performance of airlines. This construct was used in accordance with factors constraining organisational capacity of Lusthaus (2002) and Lusthaus, Murphy, and Anderson (1995).

\section{References}

Abukhalifeh, A. N., \& Som, A. P. M. (2012). Service Quality Management in Hotel Industry: A Conceptual Framework for Food and Beverage Departments. International Journal of Business and Management, 7(14), 135. http://dx.doi.org/10.5539/ijbm.v7n14p135 
Aderamo, A. J. (2010). Demand for Air Transport in Nigeria. Journal of Economics, 1, $23-31$.

Aghdaie, S. F. A., Dolatabadi, H. R., \& Adibparsa, M. (2012). Investigating the Effects of Price and Brand Leveraging Strategy on Consumer's Behavioral Intention (Case Study: Daily Food Products). International Journal of Business and Management, 7(22), 76.

Ancona, D. G. (1990). Outward bound: Strategies for team survival in an organization. Academy of Management Journal, 334-365. http://dx.doi.org/10.2307/256328

Avakov, A. V. (2010). Quality of life, balance of power, and nuclear weapons: Algora Publishing.

Bachis, E., \& Piga, C. (2006). Do prices grow more in Euro-land? Evidence from the airline industry.

Beaver, A. (2005). A dictionary of travel and tourism terminology: CABI.

Bernold, L. E., \& AbouRizk, S. M. (2010). Managing Performance in Construction. Wiley. http://dx.doi.org/10.1002/9780470638996

Brueckner, J. K., Dyer, N. J., \& Spiller, P. T. (1992). Fare determination in airline hub-and-spoke networks. The Rand Journal of Economics, 23(3), 309-333. http://dx.doi.org/10.2307/2555865

Ceha, R., \& Ohta, H. (2000). Productivity change model in the airline industry: A parametric approach. European Journal of Operational Research, 121(3), 641-655. http://dx.doi.org/10.1016/S0377-2217(99)00058-2

Chen, C. F., \& Kao, Y. L. (2011). The antecedents and consequences of job stress of flight attendants-Evidence from Taiwan. Journal of Air Transport Management, 17(4), 253-255. http://dx.doi.org/10.1016/j.jairtraman.2011.01.002

Chiou, Y. C., \& Chen, Y. H. (2010). Factors influencing the intentions of passengers regarding full service and low cost carriers: A note. Journal of Air Transport Management, 16(4), 226-228. http://dx.doi.org/10.1016/j.jairtraman.2009.11.005

Chung, K. C., \& Tan, S. S. (2008). Brand trust as quality cues in online tertiary education. International Journal of Business and Management.

Courtney, K. O., Joe, G. W., Rowan-Szal, G. A., \& Simpson, D. D. (2007). Using organizational assessment as a tool for program change. Journal of Substance Abuse Treatment, 33(2), 131. http://dx.doi.org/10.1016/j.jsat.2006.12.024

Detzen, D., Jain, P. K., Likitapiwat, T., \& Rubin, R. M. (2012). The impact of low cost airline entry on competition, network expansion, and stock valuations. Journal of Air Transport Management, 18(1), 59-63. http://dx.doi.org/10.1016/j.jairtraman.2011.09.004

Doganis, R. (1991). Flying off course: the economics of international airlines. Routledge.

Duliba, K. A., Kauffman, R. J., \& Lucas Jr, H. C. (2001). Appropriating value from computerized reservation system ownership in the airline industry. Organization Science, 12(6), 702-728. http://dx.doi.org/10.1287/orsc.12.6.702.10087

Ford, M. W., \& Evans, J. R. (2001). Baldrige assessment and organizational learning: the need for change management. Quality Management Journal, 8(3), 9-25.

Fornell, C., \& Larcker, D. F. (1981). Evaluating structural equation models with unobservable variables and measurement error. Journal of Marketing Research, 18(1), 39-50. http://dx.doi.org/10.2307/3151312

Gachino, G. (2006). Foreign direct investment, firm-level capabilities and human capital development: evidence from Kenyan manufacturing industry. Citeseer.

Gillen, D. (2010). International Air Passenger Transport in the Future. The Future for Interurban Passenger Transport: Bringing Citizens Closer Together, 95.

Gope, S., \& Hsu, M. (2011). A Case Study Of Organizational Assessment For A Non-Profit Organization For The Disabled. NABET, 44.

Guzhva, V. S., \& Pagiavlas, N. (2004). US Commercial airline performance after September 11, 2001: decomposing the effect of the terrorist attack from macroeconomic influences. Journal of Air Transport Management, 10(5), 327-332. http://dx.doi.org/10.1016/j.jairtraman.2004.05.002

Hair, J. F., Black, W. C., Babin, B. J., Anderson, R. E., \& Tatham, R. L. (2006). Multivariate Data Analysis (6th ed.). Pearson International Edition. 
Hausser, D. (1980). Comparison of different models for organizational analysis.

Hosseini, S. M., Azizi, S., \& Sheikhi, N. (2012). An Investigation on the Effect of Supply Chain Integration on Competitive Capability: An Empirical Analysis of Iranian Food Industry. International Journal of Business and Management, 7(5), 73.

Keller, T., Borges, W. J., Hoke, M. M., \& Radasa, T. (2011). Promotores and the chronic care model: An organizational assessment. Journal of Community Health Nursing, 28(2), 70-80. http://dx.doi.org/10.1080/07370016.2011.564060

Lawler, E. E., Nadler, D. A., \& Cammann, C. (1980). Organizational assessment: perspectives on the measurement of organizational behavior and the quality of work life. New York: Wiley.

Lusthaus, C. (2002). Organizational assessment: A framework for improving performance. IDRC (International Development Research Centre).

Lusthaus, C., Murphy, E., \& Anderson, G. (1995). Institutional assessment: A framework for strengthening organizational capacity for IDRC's research partners. IDRC.

Martín-Consuegra, D., \& Esteban, Á. (2007). Market orientation and business performance: An empirical investigation in the airline industry. Journal of Air Transport Management, 13(6), 383-386. http://dx.doi.org/10.1016/j.jairtraman.2007.08.001

Metzger, T. J. (2007). Evaluating Capacity Development. University of Guelph.

Nunally, J. C., \& Bernstein, I. H. (1994). Psychometric Theory. New York: McGraw-Hill.

Petrick, N. (2007). Entry and exit in the post-liberalized German airline market. GRIN Verlag.

Rajasekar, J., \& Fouts, P. (2009). Strategic alliances as a competitive strategy: How domestic airlines use alliances for improving performance. International Journal of Commerce and Management, 19(2), 93-114. http://dx.doi.org/10.1108/10569210910967860

Ramanathan, R. (2001). The long-run behaviour of transport performance in India: a cointegration approach. Transportation Research Part A: Policy and Practice, 35(4), 309-320. http://dx.doi.org/10.1016/S0965-8564(99)00060-9

Rhydderch, M., Edwards, A., Elwyn, G., Marshall, M., Engels, Y., Van den Hombergh, P., \& Grol, R. (2005). Organizational assessment in general practice: a systematic review and implications for quality improvement. Journal of Evaluation in Clinical Practice, 11(4), 366-378. http://dx.doi.org/10.1111/j.1365-2753.2005.00544.x

Salarzadeh J. H., \& Ismail, N. A. (2007). The Determination of Load Factors in the Airline Industry. International Review of Business Research Papers, 3(4), 125-133.

Segars, A. H. (1997). Assessing the unidimensionality of measurement: A paradigm and illustration within the context of information systems research. Omega, 25(1), 107-121. http://dx.doi.org/10.1016/S0305-0483(96)00051-5

Smith, S. J., \& Searle, B. A. (2010). The blackwell companion to the economics of housing: the housing wealth of nations.

Teo, T. (2010). Examining the influence of subjective norm and facilitating conditions on the intention to use technology among pre-service teachers: a structural equation modeling of an extended technology acceptance model. Asia Pacific Education Review, 11(2), 253-262. http://dx.doi.org/10.1007/s12564-009-9066-4

Valerdi, R., \& Abdimomunova, L. (2010). Organizational assessment processes for enterprise transformation. Massachusetts Institute of Technology.

Wimmers, J., Optiz, C., \& Mayer, C. (2009). Inflation Measurement: Methodology, Risks and Opportunities for Businesses. GRIN Verlag.

Zhang, L., Han, Z., \& Gao, Q. (2008). Empirical Study on the Student Satisfaction Index in Higher Education. International Journal of Business and Management, 3(9), 46. 


\section{Copyrights}

Copyright for this article is retained by the author(s), with first publication rights granted to the journal.

This is an open-access article distributed under the terms and conditions of the Creative Commons Attribution license (http://creativecommons.org/licenses/by/3.0/). 